\title{
Território: aproximações a um conceito-chave da geografia
}

\section{Territory: approaches to a geggraphy key concept

\author{
Territory:approaches to a geograph key concept
}

Arthur Breno Stürmer* Benhur Pinós Da Costa**

\section{Resumo:}

O território é um conceito imprescindível à compreensão do mundo contemporâneo. Este artigo objetiva fornecer elementos para o debate em torno da definição de território como algo dinâmico e próximo ao cotidiano. Usando a pesquisa bibliográfica, selecionou autores de orientaçôes diversas, mas não necessariamente conflitantes. Ressalta-se como resultado que o conceito de território passou a admitir novas escalas e sujeitos, diferenciando-se muito de suas primeiras definiçóes. Foi possível perceber a aproximação à realidade concreta, ao social, à identidade e sentimento de pertencimento. Conclui-se que a multiplicidade de definiçóes de território ampliou as possibilidades de uso e a complementaridade entre elas, contribuindo, assim, para a produção e o diálogo interdisciplinares nas investigaçóes científicas.

\begin{abstract}
:
The territory is a concept essential to the understanding of the contemporary world. This article aims to provide elements for the debate around the definition of territory as something dynamic and close to everyday life. Using bibliographical research, it selected authors of several theoretical orientations, but not necessarily conflicting. As a result, the concept of territory began to admit new scales and subjects, differing greatly from its first definitions. It was possible to perceive the approach to the concrete reality, to the social, to the identity and feeling of belonging. It is concluded that the multiplicity of definitions of territory extended the possibilities of use and complementarity between them, thus contributing to interdisciplinary production and dialogue in scientific investigations.
\end{abstract}

*Instituto Federal de Alagoas, Campus Palmeira dos Índios. AL - Brasil

**Universidade Federal de Santa Maria RS - Brasil
Palavras-chave:

Geografia Crítica, Teoria Geográfica, Geografia Brasileira.

Keywords:

Critical Geography, Geographic Theory, Brazilian Geography. 


\section{INTRODUÇÃO}

$\mathrm{O}$ uso generalizado do conceito de território por profissionais de diversas áreas, dentre elas a educação, cultura, segurança pública, saúde e outras, tem chamado a atenção para a variedade de seus significados. Haja vista a trajetória percorrida pelo território dentro da teoria geográfica, inúmeras definiçóes se consolidaram, contrastando com a superficialidade de certos usos e interpretaçóes.

A utilização do conceito de território sem consulta à literatura geográfica produziu inúmeras noçóes errôneas como a de território enquanto mero suporte e substrato em que se assenta uma dada população. Não obstante isso apareça em documentos oficiais que subsidiam políticas públicas e orientam açóes de governo, os erros e imprecisôes mais comuns geralmente contam com ampla divulgação por meios de comunicação de massa e mídias sociais.

Sendo o território um dos conceitos mais importantes para a Geografia, ao lado da regiáo, paisagem, lugar e espaço, é concebido como uma ferramenta útil para compreender as diferentes formas de apropriação do espaço, seu uso e ocupação. Auxilia-nos a compreender as relaçóes de poder existentes na sociedade e que justificaram sua delimitação em certos momentos históricos, assim como sua alteração e acréscimos ao longo do tempo.

Este trabalho pode servir como uma pequena introdução ou nota de advertência a respeito das definições de território, sem, porém, tomá-las como as melhores ou pretender que tenham um caráter definitivo. Os conceitos nunca estão prontos e acabados. Para Deleuze e Guatarri (1991, p. 13), "os conceitos náo nos esperam inteiramente feitos, como corpos celestes. Não há céu para os conceitos. Eles devem ser inventados, fabricados ou antes criados, e não seriam nada sem a assinatura daqueles que os criam".

Os conceitos possuem um devir, acomodam-se e superpóem-se uns aos outros, coordenando seus contornos. Resultam, de modo contínuo, da articulaçáo, corte e superposiçáo de outros conceitos, portanto apresentando contornos irregulares, dados pelos seus componentes (ibidem).

As definiçóes que serão discutidas a seguir visam a esclarecer o leitor, alertando-o para evitar, ao menos, confusôes desnecessárias em suas produçôes teóricas. $\mathrm{O}$ texto parte de algumas questóes que auxiliam na aproximação, até de maneira elementar, ao significado nuclear daquele que é considerado um conceito-chave da Geografia. Algumas questôes foram tomadas como guia, por exemplo: o que é território? Que autores trataram do território? Qual a importância do território para os estudos geográficos? Em qual escola geográfica o território foi mais utilizado? Que alteraçóes seu significado tem sofrido ao longo do tempo?

Não se pretende esgotar as possibilidades de conceituação do território nem apresentar todas as definiçôes que já lhe foram conferidas, mas realizar uma breve introdução à teorização sobre território. A intenção é auxiliar estudantes e pesquisadores da área de Geografia, Biologia, Sociologia e outras ciências que venham a se deparar com uma categoria aparentemente nova, que se oferece como simples conceito de uma ciência ou disciplina, mas que é valiosa ferramenta de análise, interpretação e reflexão.

Para o geógrafo, em especial, retomar os conceitos básicos da disciplina, no caso o território, é tarefa rotineira tão necessária quanto revisitar os principais autores dedicados ao estudo da temática territorial. Aqui se traz inúmeras acepçóes do termo, tendo em vista fornecer um panorama das definiçóes de território e propor um uso mais correto do mesmo.

\section{PRESSUPOSTOS BÁSICOS DO TERRITÓ- RIO}

O primeiro pressuposto é: território é diferente de espaço. Não só diferente, como lhe é posterior; origina-se do espaço. Mesmo a mera imagem do território que esteja contida em uma representação (cartográfica) indica que o espaço preexiste ao território. O segundo pressuposto é: a simples imagem do território equivale a uma apropriaçáo simbólica do espaço como forma primária do território. Ela também abre a possibilidade de se pensar a territorialidade, que surge quando pessoas e grupos realizam uma ocupaçáo do espaço, ainda que momentânea, esporádica e mais ou menos perceptível em seu movimento, conforme a escala em que for visualizada. Por exemplo, choque de torcidas organizadas entrando em confronto por razóes territoriais; procissóes religiosas que náo cederiam lugar a outra, no mesmo instante e local; a peregrinaçáo à Meca, ao túmulo de Lênin ou Elvys Presley, o Caminho de Santiago de Compostela com seus percursos, intinerários e peregrinos; a rota de alguma gangue suburbana ou o morro dominado pelo tráfico.

Esses produtos do imaginário social tomam emprestadas referências espaciais enraizadas e bem localizadas que são submetidas à representação, tendo uma simbologia específica e validade indeterminada. De outra forma, a presença fixa e massiva de anúncios publici- 
tários em uma rua comercial, 5th Avenue ou Wall Street, toma para si parcela do espaço inequivocadamente com a finalidade de apropriação simbólica do espaço público.

Então um pré ou prototerritório se configura apoiado no campo representacional, imaginário, ideacional, o que auxilia na referida forma de apropriação. Do mesmo modo, pela territorialidade se compreende como pode surgir um território temporário, ou seja, aquele que se constitui e destitui ao longo do tempo. $\mathrm{O}$ movimento okupa, quando toma terrenos desocupados e habitaçóes vazias para proteger seus membros ou fazer uma reuniáo com fins sociais, políticos e culturais, utiliza-os com fins territoriais. Assim o movimento LGBT e as comemorações do Dia Internacional do Orgulho Gay através de paradas, protestos e manifestaçóes de rua também constituem, como se vê em Solla (2003), territórios com tempo de existência razoavelmente definido.

Souza (2008) explorou a transitoriedade desse aspecto do território:

Territórios são construídos (e descontruídos) dentro de escalas temporais as mais diferentes: séculos, décadas, anos, meses ou dias; territórios podem ter um caráter permanente, mas também podem ter uma existência periódica, cíclica (SOUZA, 2008, p. 81).

As atividades de planejamento oficial (planos de desenvolvimento, açôes estratégicas de governo e esquemas em práticas espaciais civis e militares) evocam a imagem do território e tendem - apenas tendem - a se territorializarem. Formas de planejamento menos rígidas, como a planificação de campanhas, a organização de uma passeata, marcha, caminhada e todo tipo de mobilização popular local, global, no âmbito comunitário ou com expressáo internacional, estabelecem a existência virtual do território.

Então, para existir território, teríamos: espaço(s), ator(s) e poder(s). Espaço do qual se originará uma forma específica de relação que o ator manterá com ele; o ator (individual, coletivo, social) que se relacionará com o espaço na forma de controle, domínio, apropriação, enfim, exercendo o poder.

Podemos, ainda, ensaiar as características comuns ao território: possuir área, recursos, povo, poder, limites e fronteiras. É assim que vemos o território ao pensarmos nos conflitos agrários, lutas por demarcação de terras, bem como no zoneamento urbano, na criaçáo de corredores ecológicos ou estabelecimento de áreas verdes nos grandes centros, e assim por diante. Área, recursos, povo, poder, limites e fronteiras entram em jogo para definir o território, uma vez que são alvos diretos ou indiretos dos atores e seus poderes.

No avorecer da ciência geográfica moderna, o território foi entendido como o solo, chão (boden), e o povo, a população. Era o substrato sobre o qual se organizava a sociedade, mas de um modo a constituir um Estado - o Estado Moderno.

Para Ratzel (1990 [1914]),

\begin{abstract}
Não é possível conceber um Estado sem território e sem fronteiras (...) assim também a sociedade mais simples só pode ser concebida junto com o território que lhe pertence. $\mathrm{O}$ fato de estes dois organismos estarem ligados ao seu solo é a consequência natural da ligação evidente que une a criatura humana à Terra (RATZEL, 1990, p. 73).
\end{abstract}

O território dá solidez ao Estado, sendo um "fator constante" em relação aos acontecimento humanos e ligado ao incremento de sua potência. Em uma perspectiva, se bem que distinta, La Blache (1994) se referia também ao território do Estado, que para ele representava a unidade dos "impulsos locais" (ou dos pays). Entretanto, os territórios eram um alvo desejado não apenas pelos Estados Nacionais, mas por outras formas de organização na sociedade: "Não há nenhum grupo, mesmo no mais baixo degrau da escada social, que não tenha e não reivindique avidamente o seu território" (idem, 1954 [1921], p. 71).

Em ambos os autores, porém, predominava o entendimento de que o território resultava da força e poder do Estado como ator principal e com um papel preponderante sobre os demais, reforçando a compreensão de que é o território que permite a existência e manutenção de um Estado.

Por outro lado, o território sob comando de um Estado pode ser um meio para se chegar a determinados fins ${ }^{1}$. Ao descrever o Estado como uma construçáo histórica com a finalidade de reproduzir o capital, Kropotkin (2000 [1897]) explica, em parte, os anseios expansionistas, a formação de colônias e a busca por mercados além-mar.

Tudo isso revela a força do poder estatal que, apropriando-se de uma área (espaço), ainda é capaz de se sobrepor a outros poderes dispersos pela sociedade, ampliando seu domínio ao mesmo tempo que estabelece suas fronteiras.

1 Não há referência a Nicolau Maquiavel (1469-1527), embora se possa admitir que, se o fim de um príncipe é manter o poder, não poupará esforços em tomar territórios como meio para a conquista e manutenção do Estado, em corolário ao princípio de que o fim justifica os meios (BOBBIO, 2001) 
Raffestin (1993 [1980]) faz, ao definir território, uma ponte conceitual entre o território que é criado pelo poder de Estado e o território construído pelo poder de outros atores. Em sua definiçáo cabal de território, as relaçôes de poder estấo na origem do território, que, para ele, tem um aspecto contraditório: o poder é capaz de construir um território - projetar-se por meio dele - e, assim, limitar seu poder sobre o espaço.

Quer dizer, território

É um espaço onde se projetou um trabalho, seja energia e informação, e que, por consequência, revela relaçóes marcadas pelo poder. O espaço é a 'prisão original', o território é a prisão que os homens constroem para si (RAFFESTIN, 1993, p. 144).

Esse território abriga a materialização das ações humanas, onde "se projetou um trabalho" na forma de "energia e informação", sempre com a presença marcante do exercício do poder. Se o espaço está na origem do território, este foi gerado a partir de uma construção em que o sentido conotativo de prisão é bem oportuno: seus limites podem ser lembrados pelos muros, cercas e obstáculos/barreiras físicas ou pela sua representação nos contornos gráficos contidos em um mapa, carta, croqui ou simples folheto informativo e publicitário. O território como prisão que os homens constroem para si remete à noção de ordenamento e regulaçáo que distingue os de dentro e os de fora. O "nós" do território e os "outros" não pertencentes a ele.

\section{O TERRITÓRIO E O CONFLITO}

A formaçấo, manutenção e perda de um território estão implicadas por algo além do espaço, ator e poder. Sem o elemento conflito, territórios seriam fruto de (des)apropriaçóes consensuais, invasões sem força opositora ou guerras sem mortos e feridos. Pelo menos a certa altura da história, passa a não haver território sem divergências, antagonismos, embates, ofensivas, resistências e reações.

Para Zibechi (2015),

Em nosso continente, existem territórios heterogêneos, porque os povos do nosso continente resistiram e resistem à dominaçáo, sustentantdo e criando territórios onde podem habitar os modos de vida não hegemônicos. Nem a diferença sociocultural, nem os territórios que a hospedam são dados de realidade, mas construçôes cotidianas. Longe de serem essências, trata-se de criações e recriaçôes permanentes (ZIBECHI, 2015, p. 99).

O conflito é permanente, portanto, devido às assimetrias de poder na disputa pelos territórios - não só na conquista e manutenção, mas na resistência - do que resulta serem desconstruídos, deformados, transfigurados ou extintos. De maneira geral se diz que o território encarna "o conflito social [que] é um conflito territorializado" (ibidem, p. 100).

A dimensão conflituosa consta na definição de território em Souza $(2005 ; 2008 ; 2013$, p. 78 , grifo do autor): "é fundamentalmente um espaço definido e delimitado por e a partir de relaçóes de poder". Tal definição, segundo Schneider e Tartaruga (2005), comporta, ao mesmo tempo, uma face restritiva dada pela ênfase na ideia de poder e uma face ampla, dada pela aceitaçáo das dimensóes social, política, cultural e econômica. A face restritiva corresponde a um limite (alteridade) nem sempre amigável - é o "outro" que, além da área do território, é detentor de um poder. A face ampla dá a ideia de um território que resulta de múltiplas determinaçóes e em diferentes escalas, pois as relaçóes de poder que delimitam o espaço para formar um território as perpassam em vários sentidos e direçóes.

Zibechi (2015) reconhece que o conceito de território, por sua vez, introduz uma nova forma de ver o conflito social, agora ligado às relaçóes sociais e de poder que dão forma aos territórios. Mesmo diante da contínua desestruturaçáo dos territórios e da permanente reconfiguração, se pode ler o conflito por todas suas dimensóes: local e global, sem ovidar das dimensões política e cultural.

\section{TERRITÓRIO E CONDIÇÓES TERRITO- RIAIS}

Costa (2010), fala de três condiçóes territoriais que, nos movimentos de modernização e contra-modernização, mudam a face da relação natureza-sociedade. A primeira condição territorial é o espaço social em si, tomado como espaço da reproduçáo da sociedade. Nela se combinam homogeneidade, funcionalidade e regramento moral dos comportamentos humanos. A segunda condição territorial aparece no momento em que há uma fragmentaçáo do espaço urbano pelo território (em diferentes escalas) e microterritorialização (de diferentes sujeitos), combinando, agora, a contestaçáo, a organicidade e outras apropriaçóes que se somam e ao mesmo tempo se opóem à condição territorial anterior. A terceira condição territorial surge como produto misto de forças de homogeneização/diversificação e o espaço social tornado orgânico:

$\mathrm{O}$ (micro)território(lização) contém aquilo que é referência à 
sociedade, aquilo que é desvio dela (identidades desviantes, estigmas) e aquilo que escapa às duas coisas (espontaneidades e singularidades múltiplas em agregaçóes territorializadas) (COSTA, 2010, p. 112).

As três condiçóes territoriais deixam claro que o elemento de conflito presente na segunda condição é que foi responsável por fazer emergir a coexistência entre o que é "referência" e "desvio" na sociedade. A última condição do território, vale ressaltar, só é possível em se considerando a escala micro, os sujeitos individuais e o caráter social que os envolve.

O território entendido como processo feito de dentro para fora se faz em escala micro e, se ele for a prisão que os homens controem para si, o é também por um sentimento de segurança quanto ao espaço aberto e perigoso. Criam-se fronteiras entre o "meu mundo" e o "mundo dos outros" que podem ser meus inimigos. Produz-se território como prisão devido à necessidade da construção de um entendimento específico de mundo em detrimento do desconhecido que está fora do território, isto é, além de suas bordas. Isto se processa em meio ao cotidiano das coisas conhecidas e produzidas desde o indivíduo.

Admitida a micro-escala, é preciso frisar que há territórios em diversas escalas geográficas. A pessoa isoladamente, os grupos, as tribos urbanas e os coletivos igualmente fixam limites, separam-se por fronteiras, usam o espaço e dele tomam posse: formam territórios.

Heidrich (2009) alerta quanto à variedade de escalas territoriais e territorialidades, que constituem elo ou relação (de fixação, separação, uso, posse) entre ator e objeto:

Um outro aspecto importante na compreensão dessa relaçáo é o fato de que ela ocorre em diversas escalas geográficas, que variam do âmbito da ação do indivíduo ao âmbito da ação das sociedades políticas, mas sempre estará ligada à objetividade de um ator. Tanto o domínio territorial do estado como o cercamento e uso de pequenas porçôes de espaço, dizem respeito a essas relaçôes. Como derivam de açôes sociais, a elas poderão estar associadas o desenvolvimento de concepçóes pertinentes ao domínio e ao uso (HEIDRICH, 2009, p. 275).

Gomes (2002), embora não se refira especificamente ao território, fornece uma chave de entendimento do território a partir do que chama de nomoespaço e genoespaço. Eles tratam indiretamente da questão da escala ao entremostrar o tipo de ator territorial, o elo estabelecido por este com o espaço e a extensão, e o grau de domínio e uso do espaço que deu origem ao território. Territórios de maior escala2, cujo poder é exercido, num extremo, pela sociedade, têm "extensão física, $2 \quad$ Aqui e adiante, ao se falar em escala, trata-se de escala geográfica, e não cartográfica.

Geografia, Ensino \& Pesquisa, Vol. 21 (2017), n.3, p. 50-60

ISSN: 2236-4994 DOI: 10.5902/2236499426693 limitada, instituída e regida pela lei” (nomoespaço), enquanto territórios de menor escala, onde o poder é exercido por um grupo ou comunidade, tem fronteiras fluidas, pois são "territórios de conflito, reivindicação e reprodução da idelogia central da diferenciação" (geonoespaço) (GOMES, 2002, p. 37, p. 63).

Assim, indo-se de uma escala a outra de análise, o quarto elemento do território (o conflito) torna-se mais perceptível. A prisáo que os homens constroem para si ebuli de dentro para fora, do menor para o maior espaço. Torna-se diferente, muda e se altera mediante o embate entre a "lei geral" e a "vontade individual". Enquanto o termo genoespaço se aproxima do conceito de território, empresta-lhe características de identidade própria, resistência, certa "rugosidade" (Ver SANTOS, 2008) e, não obstante, capacidade de luta, mobilização, e diferenciação; portanto guarda potencial de mudança.

\section{ESCALA TEMPORAL E TERRITÓRIO DI- NÂMICO}

Além da escala geográfica, propriamente espacial, há a escala temporal, histórica, pois os territórios podem ter existência longa e duradoura ou curta, efêmera, momentânea e ocasional, ainda que com certa regularidade.

Souza (2008, p. 81), afirma que os territórios são construídos e desconstruídos, podendo ter caráter permanente ou existência periódica, cíclica, ou seja, não precisam ou devam estar reduzidos à escala nacional e associados à figura do Estado. $\mathrm{O}$ autor ainda toma o território por "relaçóes sociais projetadas no espaço" (ibidem, p. 87, grifo do autor), o que aponta para a formação, dissolução, constituição e dissipação relativamente rápidas dos territórios e para a sua instabilidade e existência periódica - com o substrato espacial permanecendo ou não o mesmo.

Por isso, o território corresponde a:

Um campo de forças, uma teia ou rede de relaçốes sociais que,
a par de sua complexidade interna, define, ao mesmo tempo,
um limite, uma alteridade: a diferença entre "nós" (o grupo, os
membros da coletividade ou "comunidade", os insiders) e os
"outros" (os de fora, os estranhos, os outsiders) (SOUZA, 2008,
p. 86, grifo do autor).

Isso equivale a dizer que o território se conforma a partir da sociedade. Embora o território venha do espaço, é moldado pela sociedade. Nesta acepção, a projeção de forças sociais, tal qual um campo de forças, ou, ainda, uma teia ou rede de relaçoóes sociais, é algo que depende certamente da configuração das forças existen- 
tes na sociedade. O território, ao invés de se originar de uma instância (somente) da sociedade, como em Santos $(2004 \text {, p. } 177)^{3}$, passa a ser visto como algo mais dinâmico e não por acaso ligado aos indivíduos e grupos dessa sociedade. Pulverizam-se então os territórios e se multiplica o número de agentes territoriais. Seus movimentos criam e desfazem territórios que já não são obrigatoriamente contínuos, não correspondem necessariamente a grandes extensóes físicas e não estão submetidos exclusivamente ao poder estatal ou a uma única fonte de poder.

Advém, então, um território submetido a forças não raro opostas, que lhe conferem dinamicidade. Agentes territoriais antes ignorados conformam um território mais complexo. Passa-se da imagem de território consolidado e estável para outra em que sujeitos plurais, com interesses diversos e em um intervalo de tempo bem mais reduzido tendem a se mover na menor escala geográfica ${ }^{4}$. Compreender a menor parte de um todo - o espaço geográfico - leva mais diretamente ao real, senão à verdade sobre a sociedade e o espaço.

Considerar o fragmento menor, o local da experiência, o espaço vivido, o lócus do cotidiano como recortes alternativos para as análises territoriais é tendência que contraria grande parte da tradição entre as grandes escolas geográficas, apesar do potencial metodológico que traz ao pesquisador.

Walter Benjamin (1984) reafirma a importância dos pormenores para se chegar à verdade ${ }^{5}$, utilizando-se da figura do mosaico:

O mosaico, na fragmentaçáo caprichosa de suas partículas, não
perde sua majestade. Tanto o mosaico como a contemplação
justapóem elementos isolados e heterogêneos, e nada manifes-
ta com mais força o impacto transcendente, quer da imagem
sagrada, quer da verdade. O valor desses fragmentos de pensa-
mento é tanto maior quanto menor sua relação imediata com
a concepção básica que lhes corresponde, e o brilho da repre-
sentaçáo depende desse valor da mesma forma que o brilho do
mosaico depende da qualidade do esmalte. A relação entre o
trabalho microscópico e a grandeza do todo plástico e intelec-
tual demonstra que o conteúdo de verdade só pode ser captado
pela mais exata das imersóes nos pormenores do conteúdo ma-
terial (BENJAMIN, 1984, p. 50-51).

É dessa menor escala - geográfica e não escala cartográfica -, que pode ser até micro (Ver COSTA, 2016),

\footnotetext{
3 Ressalva se faça em relação ao entendimento de M. Santos, para quem o espaço é construído a partir e sobre o território - posiçáo oposta à de Raffestin (1993), aqui adotada, em que o espaço é anterior ao território. 4 Adverte-se que a "menor escala", aqui, é escala geográfica, de extensão territorial "menor"

$5 \mathrm{~W}$. Benjamin diferencia conhecimento e verdade. Conhecer implica construir o objeto na consciência, que se apropria dele. Há um caráter possessivo no conhecimento. A verdade escapa às formas de projeção do conhecimento, tem um status ontológico e existe como ser (MACHA-
} DO, 2004). que se extrairá o "conteúdo de verdade” sobre o território. Se as relaçóes de poder nele presentes emanassem apenas do Estado, como poder público, ocultar-se-ia, como demonstrou Souza (2008), a complexidade interna ao território, bem como a rede de relaçóes sociais das escalas menores (grupo, comunidade) e se ignorariam as diferentes escalas espaciais e temporais de construção dos territórios.

Por que não se pensar o território na escala geográfica local a partir das relaçóes de poder ali presentes? Território como espaço definido e delimitado por e a partir de relaçóes de poder? Considerar o território como algo que se refira não apenas à ação de governos, com seu poder formal, oficial, "legítimo", mas como aquele poder emanado de cada cidadão, sujeito, indivíduo? - um poder pouco ou nada reconhecido, geralmente ignorado, desprezado e forçadamente subordinado em sua vontade e representatividade.

\section{A HETERONOMIA QUE CEGA AOS GEÓ- GRAFOS}

As grandes escolas reconhecidas pela historiografia da Geografia dedicam um esforço significativo à compreensão do território como construção do poder público, estatal, governamental e oficial. A tônica no discurso geográfico já esteve muito assentada na visibilidade das açóes do poder público, planejadas, organizadas e burocratizadas, em detrimento da percepção do território como algo criado e mantido pelo poder que emana do(s) indivíduo(s). Considerando que há sujeitos ativos que às vezes pouco dependem do poder público para levar sua vida adiante, pode-se adotar posturas que permitam visualizar o movimento de construção dos territórios pelas vozes isoladas, fragmentadas e desassistidas.

A Geografia aderiu à sociedade heterônoma, que solapa as possibilidades de se conceber a formação dos territórios, a territorialização e a territorialidade a partir da iniciativa do indivíduo, da autonomia individual. $\mathrm{Na}$ condição de hetoronomia social, segundo Castoriadis (1995, p. 131), a autonomia individual torna-se limitada e quase inútil diante das condiçóes de privação e de opressão que se apresentam "como estrutura solidificada global, material e institucional de economia, de poder e de ideologia, como indução, mistificação, manipulação e violência". Prolatar o "discurso do outro", legitimando-o através de mapas, planos, projetos, regionalizaçóes, leis, acordos internacionais e situando-o no anonimato coletivo alimenta a alienação como fenômeno social: eis 
como sempre foi comum entre os geógrafos.

Agentes sociais concretos na menor escala do território

Para Corrêa (1999), o espaço (urbano capitalista) é produzido por agentes sociais concretos classificáveis em cinco categorias, cujas açóes são complexas e realizadas dentro de um marco jurídico que reflete o interesse de um agente dominante capaz de gerar a segregação espacial, limitando a atuação espacial dos grupos sociais excluídos:

Os grupos sociais excluídos tornam-se, efetivamente, agentes modeladores, produzindo seu próprio espaço, na maioria dos casos independentemente e a despeito dos outros agentes (CORRÊA, 1999, p. 30).

O espaço concebido por Corrêa (idem) trata-se de um território onde os "agentes sociais" que o produzem são agentes territoriais ativos em conflito aberto com outros agentes, empreendendo ações marcadas antes pelo agir autônomo que guiados ou sublinhados pelo rótulo de classe.

Tal território, assinala o autor,

É também o lugar onde as diversas classes sociais vivem e se reproduzem. Isto envolve o quotidiano e o futuro próximo, bem como as crenças, valores e mitos criados no bojo da sociedade de classes e, em parte, projetados nas formas espaciais: monumentos, lugares sagrados, uma rua especial, etc. Mas o quotidiano e o futuro próximo acham-se enquadrados num contexto de fragmentaçáo desigual do espaço, levando aos conflitos sociais (...). Eis o que é o espaço ubano: fragmentado e articulado, reflexo e condicionante social, um conjunto de símbolos e campo de lutas. É assim a própria sociedade em uma de suas dimensóes, aquela mais aparente, materializada nas formas espaciais (CORRÊA, 1999, p. 9).

Aqui se percebe que na menor escala - em que se visualizam os agentes sociais da produção do espaço - conflitos aparecem como um dado significativo juntamente à dimensão simbólica e sua projeção no espaço. Este, é evidente, situa-se no contexto da fragmentaçáo desigual do espaço. Em síntese, um conjunto de símbolos e campo de lutas remete ao cotidiano, à escala local, aos grupos e às comunidades.

É oportuno associar este espaço (social) com o que se denominará de território usado, que compóe "nosso quadro de vida" e isso inclui não apenas as formas, mas os "objetos e ações, [sendo] sinônimo de espaço humano, espaço habitado" (SANTOS, 1998, p. 15-16). Em outras palavras, o território é o chão, a populaçáo e sua identidade com o território, constituindo-se o lugar da vida, da residência, das trocas materiais e espirituais, além de fundamento e base do trabalho (idem, 2002; 2008).

Poderia se falar em território-lugar, que

É uma das formas para compreender e explicar as relaçôes de poder, as identidades, os pertencimentos, as diferenças etc. (...). O território-lugar constitui-se numa relaçáo espaço-tempo em que o povo vive, sente, percebe, aspira, sofre, interage (social, espiritual e naturalmente), coopera, disputa, luta, resiste, degrada, preserva, é extorquido, explorado e subordinado (SAQUET, 2014, p. 27)

Dematteis (2013) também percebeu no território a produção de relaçóes intersubjetivas ligadas ao produzir e ao viver, mas principalmente mediando relaçóes sociais voltadas à produção:

O território, assim, resulta como conteúdo, meio e processo de relaçôes sociais. Essas relaçốes sociais que são, ao mesmo tempo, materiais, substantivam o território. (...) território entendido como conflito social (...) no qual o território é mediador das relações sociais de produção (DEMATTEIS, 2013, p. 8-9).

Vale et al (2005) sintetiza as dimensóes econômica, política e cultural6 na sua definição de território:

O território não é somente relaçôes sociais; simultaneamente, significa também a materialidade das formas espaciais dos processos sociais de dominação e controle; é fluxo, conexão e enraizamento. $\mathrm{O}$ território é efetivado quando ocorre a manifestação e se exerce qualquer tipo de poder, de relaçóes sociais, pois são estas que consubstanciam o poder e que os homens mantêm entre si na vida cotidiana, concluindo assim que, onde existem homens há relaçóes e, têm-se, ao mesmo tempo, territórios. As relaçóes são o poder e o poder são as relaçóes e são estas que cristalizam o território e as territorialidades plurais (VALE et al, 2005, p. 16).

Esse território fruto de uma construção social, resultante de processos de apropriação e domínio do espaço, realizando-se cotidianamente, inscreve-se num campo de poder. Se quisermos dizer, num campo de relaçôes de natureza socioespacial. Como dito acima, as relaçôes entre os homens, envolvendo o poder, cristalizam o território e as territorialidades plurais.

De modo diverso, mas dando peso à materialidade e ao social, vemos em Milton Santos uma concepção de território em que o mesmo antecede o espaço geográfico. É um contraponto necessário à reflexão epistemológica da Geografia que, por longo tempo, resistiu à renovação teórico-metodológica. Entretanto, na obra deste autor o conceito de território foi atualizado a pon- 
to de estar à altura dos desafios trazidos pelas temáticas emergentes à virada do século XX para o XXI. Desde então o território passou a ser "uma forma impura, um híbrido, uma noção que, por isso mesmo, carece de constante revisão histórica. $\mathrm{O}$ que ele tem de permanente é ser nosso quadro de vida" (SANTOS, 2005, p. 255).

A ele também se atribui a retomada do conceito de território na Geografia, razão pela qual é oportuno examinar sete de suas obras-primas, que ora tangenciam o conceito de território, ora mantêm-no inalterado e por vezes dão um salto na evolução desse conceito.

\section{TERRITÓRIO NA OBRA DE MILTON SAN- TOS}

Milton Santos produziu uma evoluçáo positiva no conceito de território, como se verifica nos aperfeiçoamentos que fez ao longo de três décadas para chegar a novas compreensóes sobre o território.

Por uma Geografia Nova (SANTOS, 1978) tem o território que, sendo utilizado pelo povo, cria o espaço. Sua principal característica é ser imutável, portanto um dado fixo. O território também é compreendido como o espaço de uma nação, resultante da ação homem e seu trabalho, permeado pelas relaçóes sociais e diferentes formas de ocupação e produção. Espaço e sociedade (SANTOS, 1979) mostra o território como palco do capital que prolifera através da divisão internacional do trabalho, especialmente nos países periféricos, onde a apropriação da mais-valia é acompanhada da desvalorização de recursos controlados pelo Estado e da supervalorização das grandes empresas.

$\mathrm{Na}$ década de 1980, Espaço e método (SANTOS, 1985) traz o território associado à ideia de palco das atividades criadas a partir da herança cultural de um povo. O território deixa de ser apresentado como forma definitiva, imutável, pois agora encontra-se articulado ao espaço mundial. Metamorfoses do espaço habitado (SANTOS, 1988) reflete o momento histórico. O território apresenta especializaçóes e recebe novos papéis, tendo suas partes (lugares) sofrido uma revalorização. Nota-se que espaço e territórios reorganizam-se:

O território a cada momento foi organizando-se de maneira diversa, muitas reorganizaçóes do espaço se deram e continuam acontecendo, atendendo aos reclamos da produção da qual é arcabouço. Merecem destaque especial as transformaçóes ocorridas a partir de meados deste século [XX] (SANTOS, 1988, p. 17).
Já na obra Técnica, espaço, tempo (SANTOS, 1994), o território inclui ciência, tecnologia e informação: é a superposição de sistemas de engenharia diferentemente datados e usados segundo tempos diversos. $\mathrm{O}$ território é atingido pelo processo de racionalização da sociedade, passando a servir-lhe de instrumento fundamental:

Cada fração do território é chamada a revestir características específicas em função dos atores hegemônicos, cuja eficácia depende doravante de uma produtividade espacial, fruto de um ordenamento intencional e específico (SANTOS, 1994, p. 24).

Complexa e academicamente significativa, A natureza do espaço (SANTOS, 1998) traz a compreensão do território como território usado. Ele é histórico e seus objetos têm conteúdo técnico e social. O espaço contém o território modelado, configurado, correspondendo aos complexos naturais e às construçóes/obras feitas pelo homem: estradas, plantações, fábricas, casas, cidades. $\mathrm{O}$ território é construído historicamente, cada vez mais, como negação da natureza natural, revelada pelos objetos, que têm uma gênese e conteúdo de caráter técnico e social. Os mesmos estão organizados em sistemas e com influência direta no uso do território - que é usado, reorganizado, configurado, normatizado, racionalizado. Há porções de territórios com objetos e ações, normas (técnicas, políticas e jurídicas), ritmos, heterogeneidades e agentes. São parcelas territoriais específicas que se formam no espaço, denominadas territórios locais normativos. Aqui, para compreender o território, recorta-se o espaço, porém segundo uma concepçáo ampla e profunda deste conceito.

De modo bem distinto, Por uma outra globalizaçáo (SANTOS, 2008) esboça o território esquizofrênico. Este acolhe vetores da globalização que impóem nova ordem, ao mesmo tempo em que se produz uma contraordem. O movimento geral da sociedade planetária e o movimento particular de cada fração regional ou local da sociedade nacional se associam e se chocam. Ao lado da compartimentação do território, o processo de fragmentaçáo rouba às coletividades o comando do seu destino e os novos atores não dispóem de instrumentos de regulação que interessem à sociedade em seu conjunto. Neste cenário, o território como placo vira ator. Emerge um território que "age" sobre açōes e consciências: 
O território não é um dado neutro nem um ator passivo. Produz-se uma verdadeira esquizofrenia, já que os lugares escolhidos acolhem e beneficiam os vetores da racionalidade dominante mas também permitem a emergência de outras formas de vida. Essa esquizofrenia do território e do lugar tem um papel ativo na formação da consciência (SANTOS, 2008, p. 80).

O território, agora, deixa transparecer a identidade e o pertencimento, que são aspectos por vezes negligenciados no trato desse conceito, especialmente quando o elemento humano é sacrificado na abstração das análises territoriais excessivamente técnicas. Essa concepção de território estreita a relação entre território e população, juntamente com as implicaçóes que acompanham essa relação: a identidade, o sentimento de pertecimento e o que preenche o cotidiano das pessoas.

A partir daí, o conceito de território ganha, definitivamente, uma conotação social forte, muito distante daquela que predominou nas escolas geográficas anteriores e em praticamente todo o século XX. O território de que se fala já não diz respeito somente àquele dos documentos oficiais, referentes à organização político-administrativa, manuais e tratados, pois vem a se carregar da sua face cotidiana, onde há movimento, conflito, lutas e resistências.

\section{CONSIDERAÇÓES FINAIS}

A pretensão deste trabalho foi a de construir um panorama das definiçóes do conceito de território apoiada na produçáo de geógrafos contemporâneos, que servisse de subsídio a novas reflexóes teóricas sobre o tema. A multiplicidade de definições trazidas teve por função esboçar uma trajetória possível para o conceito de território, tendo implícita a evolução histórica e a característica de mutabilidade que o acompanha.

Concluir com as definições de Milton Santos não quis significar que os seus conceitos de território foram ou são os melhores, nem os mais recentes em termos cronológicos, mas exemplicar a necessidade que há - como o fez este autor - de revisáo dos conceitos ao longo do tempo. Como se afirmou de início, os conceitos não se acham prontos e acabados, mas possuem um devir. Servem mais a uma época que outra e refletem o contexto histórico e geográfico - temporal e espacial; cabem-lhe terminalidade, mas são retomados e se renovam com o pensamento dos mesmos ou novos autores.

O conceito de território, atualmente central para a Geografia, não teve seu entendimento esgotado aqui, embora tenha sido mostrado como uma ferramenta de análise e interpretação da realidade social que pode deflagrar novas reflexóes e concepçôes no percurso investigativo de pesquisas, especialmente entre as Ciências Sociais, Humanas e da Saúde.

Acredita-se que, da definição de território trazida por Raffestin (1993 [1980]) àquelas nascidas e incrementadas pela teoria miltoniana do espaço, todas guardam um poder explicativo sobremaneira válido para interpretarmos a realidade do território em tempos de globalização/fragmentação. Tais concepçóes caracterizam o território como permeado pelas relaçóes de poder, que fundam o território, portanto dependem da ação de sujeitos, mas sujeitos de carne e osso, vida e sentimento, com rotinas, cotidianos e um determinado lugar social. Entre esses sujeitos há representantes das camadas pobres da sociedade, portadores de uma identidade defendida com unhas e dentes e que lhes dá motivos para resistir ao esfacelamento do território (fragmentação) e à desagregação comunitária (isolamento).

O conceito de território, tendo ficado relativamente esmaecido por longa data na teoria geográfica, hoje retorna com potencial para auxiliar na descrição, interpretação e análise social e espacial do espaço geográfico. A multiplicidade de definiçôes de território disponíveis aos estudiosos ampliou as possibilidades de uso e a complementaridade entre elas, o que contribui para a produção e o diálogo interdisciplinares táo visados nas investigações científicas d'vant-garde.

Além de ser uma ferramenta útil para compreender as diferentes formas de apropriação do espaço, seu uso e ocupação, o conceito de território conseguiu superar o distanciamento que o afastava da realidade concreta do dia a dia do homem comum, do sujeito anônimo, trabalhador, ator social, liderança de bairro, e aproximar-se do território-chão, lugar de vida, que é onde as coisas acontecem.

\section{REFERÊNCIAS}

BENJAMIN, Walter. Questóes introdutórias de crítica do conhecimento. In: Origem do drama barroco alemão. Trad. Sérgio Paulo Rouanet. São Paulo: Brasiliense, 1984.

BOBBIO, Norberto. A teoria das formas de governo. 10. ed. Trad. Sérgio Bath. Brasília: Editora UnB, 2001.

CASTORIADIS, Cornelius. A instituiçáo imaginária da sociedade. 3. ed. Trad. Guy Reynauld. Rio de Janeiro: Paz e Terra, 1995

CORRÊA, Roberto Lobato. O espaço urbano. 4. ed. São Paulo: Ática, 1999. 
COSTA, Benhur Pinós da. O espaço social, os sujeitos e as múltiplas microterritorializações urbanas. In: PEREIRA, Sílvia Regina; COSTA, Benhur Pinós da; SOUZA, Edson Clemente de (Orgs.). Teorias e práticas territoriais: análises espaço-temporais. São Paulo: Expressão Popular, 2010. p. 99-114.

Geografia e cotidiano: reflexóes sobre teoria e prática de pesquisa. In: HEIDRICH; Álvaro Luiz; PIRES, Cláudia Zeferino (Orgs.). Abordagens e práticas da pesquisa qualitativa em geografia e saberes sobre espaço e cultura. Porto Alegre: Letra1, 2016. p. 129-149.

DELEUZE, Gilles; GUATARRI, Félix. O que é a Filosofia? Rio de Janeiro: Editora 34, 1991.

DEMATTEIS, Giuseppe. O território: uma oportunidade para repensar a geografia. In: SAQUET, Marcos Aurelio. Abordagens e concepçóes sobre território. 3. ed. São Paulo: Outras Expressóes, 2013. p. 7-11.

GOMES, Paulo da Costa. A condiçáo urbana: ensaios de geopolítica da cidade. Rio de Janeiro: Bertrand Brasil, 2002.

HEIDRICH, Álvaro Luiz. Conflitos territoriais na estratégia de preservação da natureza. In: SAQUET, Marcos Aurelio; SPOSITO, Eliseu Savério (Orgs.). Territórios e territorialidades: teorias, processos e conflitos. São Paulo: Expressão Popular, 2009. p. 271-290.

KROPOTKIN, Piotr Alekseievitch. O Estado e seu papel histórico. São Paulo: Imaginário, 2000.

LA BLACHE, Vidal de. Princípios de Geografia Humana. 2. ed. Lisboa: Ediçóes Cosmos, 1954.

Tableau de la Geógraphie de la France. Paris: Le Table Ronde, 1994.

MACHADO, Francisco Pinheiro. Imanência e história: a crítica do conhecimento em Walter Benjamin. Belo Horizonte: Editora UFMG.

RAFFESTIN, Claude. Por uma geografia do poder. São Paulo: Editora Ática, 1993.

RATZEL, Friedrich. Geografia do homem (Antropogeografia). In: MORAES, Antonio Carlos Robert de (Org.). Ratzel. São Paulo: Ática, 1990. p. 33-107.

SANTOS, Milton. Por uma Geografia Nova. São Paulo: Hucitec; Edusp, 1978.

Espaço e Sociedade. Petrópolis, RJ: Vozes, 1979.

Espaço e método. São Paulo: Nobel, 1985. citec, 1988.

Metamorfoses do espaço habitado. Paulo: $\mathrm{Hu}-$
1994.

Técnica, espaço, tempo. São Paulo: Hucitec,

A natureza do espaço. São Paulo: Hucitec, 1998.

Território e Dinheiros. In: Território Territórios.

Niterói, RJ: Programa de Pós Graduação em Geografia - PPGEO-UFF/AGB, 2002.

Por uma Geografia Nova: da crítica da geografia a uma Geografia Crítica. 6. ed. Sáo Paulo: Editora da USP, 2004.

- Territorio y movimentos sociales. Debates, Buenos Aires, Observatorio Social de América Latina, CLACSO, ano 6, n. 16, jan.abr., p. 251-261, 2005.

Por uma outra globalizaçáo: do pensamento único à consciência universal. 16. ed. Rio de Janeiro: Record, 2008.

SAQUET, Marcos Aurelio. Abordagens e concepçóes de território. São Paulo: Expressão Popular, 2007.

- Participação social em territórios de identidade e desenvolvimento numa práxis dialógica e cooperada. In: SILVA, Onildo Araújo da; SANTOS, Edinusia Moreira Carneiro; COELHO NETO, Agripino Souza (Orgs.). Identidade, território e resistência. Rio de Janeiro: Consequência, 2014. p. 11-36.

SCHNEIDER, Sergio; TARTARUGA, Iván Peyré. Território e abordagem territorial: das referências cognitivas aos aportes aplicados à análise dos processos rurais. Raízes, Campina Grande, Universidade Federal de Campina Grande, v. 23, n. 1 e 2, p. 99-117, jan./dez. 2005.

SOLLA, Xosé Santos. Espacios disidentes en los processos de ordenación territorial. Pegada, v. 4, n. 2, p. 87-119, nov. 2003. (Trad. livre)

SOUZA, Marcelo Lopes de. O desafio metropolitano: um estudo sobre a problemática sócio-espacial nas metrópoles brasileiras. 2. ed. Rio de Janeiro: Bertrand Brasil, 2005.

. O território: sobre espaço e poder, autonomia e desenvolvimento. In: CASTRO, Iná Elias de; GOMES, Paulo da Costa; CORREAA, Roberto Lobato (Orgs.). Geografia: conceitos e temas. 11. ed. Rio de Janeiro: Bertrand Brasil, 2008. p. $77-116$.

Os conceitos fundamentais da pesquisa sócio-espacial. Rio de Janeiro: Bertrand Brasil, 2013.

VALE, Ana Farias; SAQUET, Marcos Aurelio; SANTOS, Roseli Alves dos. O território: diferentes abordagens e conceito-chave para a compreensão da migração. Revista Faz Ciência, Francisco Beltrão, PR, Universidade do Oeste do Paraná, v. 7, n. 1, p. 11-26, 2005. 
ZIBECHI, Raúl. Territórios em resistência: cartografia política das periferias latino-americanas. Rio de Janeiro: Consequência, 2015.

\title{
Correspondência do autor:
}

\author{
Arthur Breno Stürmer \\ arthur.sturmer@gmail.com \\ Benhur Pinós Da Costa \\ benpinos@gmail.com
}

\begin{abstract}
ARTIGO RECEBIDO EM: 15/04/2017
\end{abstract}
REVISADO PELO AUTOR EM: 07/08/2017

ACEITO PARA PUBLICAÇÃO EM: 07/08/2017 